\title{
ANALISIS PROSES PENGECORAN DAN PERMESINAN BUSHING RODA KERETA DI GALANGAN KAPAL
}

\author{
Nanda Dwiguna1), Akhmad Syarief ${ }^{2)}$ \\ 1,2Program Studi Teknik Mesin \\ Fakultas Teknik Universitas Lambung Mangkurat \\ JL. Akhmad Yani Km.36 Banjarbaru, Kalimantan Selatan,70714 \\ Telp. 0511-4772646, Fax 0511-4772646 \\ E-mail : march_guna@yahoo.co.id
}

\begin{abstract}
This study aims to know the process of making brass bushing to succeed into a product along with the value of violence and roughness. Methods used include evaporative method, $\mathrm{CO}_{2}$ sand mold and method $x$. This research is done by first preparing tools and materials then done casting process where brass used in melted then cast into casting castings and in chill with well water. Furthermore, the machining process using a lathe with carbide chisel and engine rotation used for 590 RPM. From roughness test result after machining process got value at outside diameter of point $A 2,532 \mu \mathrm{m}$, point $B$ equal to 2,544 $\mu \mathrm{m}$, point $C$ equal to 2,673 $\mu \mathrm{m}$, then diameter in point $A$ equal to $1,539 \mu \mathrm{m}$, point $B$ equal to 1,749 $\mu \mathrm{m}$. For the value of hardness on the method of sand mold CO2 obtained an average value of $42 H R_{B}$, evaporative methods of $33.2 H R_{B}$ and method $x$ obtained an average value of 39.8 $H R_{B}$. From these results it is known that the hardness of the best bushing in this research is by the method of sand mold $\mathrm{CO}_{2}$ because it has good heat resistance and good mold density.
\end{abstract}

Keywords: metal casting, machining process, brass

\section{PENDAHULUAN}

Kuningan merupakan logam yang mengandung campuran dari suatu tembaga dan seng. Tembaga ini adalah suatu komponen utama yang dimiliki kuningan, dan kuningan ini biasanya diklasifikasikan menjadi paduan tembaga. Untuk warna kuningan ini bervariasi dimulai dari warna coklat kemerahan gelap sampai ke cahaya kuning keperakan, pengaruh perubahan warna ini tergantung pada banyaknya jumlah kadar seng. Seng akan memiliki lebih banyak pengaruh warna pada kuningan. Kuningan merupakan suatu benda yang mudah di bentuk dan juga sebuah konduktor panas yang baik serta umumnya tahan terhadap korosi dari air garam.

Pengecoran logam adalah suatu proses pengolahan benda yang dilakukan dengan beberapa cara dimulai dari membuat pola, cetakan, peleburan, penuangan cairan logam hingga membongkar dan membersihkan coran. Dari semua jenis logam yang memiliki bentuk rumit yang terbuat dari logam ferro ataupun non ferro yang memiliki ukuran kecil sampai ukuran besar dapat diolah dengan melakukan proses pengecoran. Metode yang digunakan ialah dengan pengecoran cetakan pasir.

Proses permesinan sangat berperan penting di dunia industri manufaktur karena berguna untuk menciptakan alat atau komponen produk mesin yang berbahan dasar dari logam. Mesin yang digunakan ialah mesin bubut dengan pahat karbida. 


\section{Pengecoran Logam}

Pengecoran logam merupakan proses pengolahan benda dengan bahan logam apa saja dengan cara mencairkan logam tersebut kemudian dituang ke dalam rongga cetakan. Proses ini pada dasarnya digunakan untuk membuat suatu benda dengan bentuk yang rumit dan dapat diproduksi secara masal. Dengan menggunakan teknik pengecoran yang benar. Berbagai jenis logam seperti, besi, baja dan paduan tembaga. Dapat dilakukan dengan proses pengecoran logam. Proses pengecoran logam merupakan proses yang berkesinambungan dan saling terkait dari berbagai proses yang ada, seperti yang terlihat pada Gambar 1.

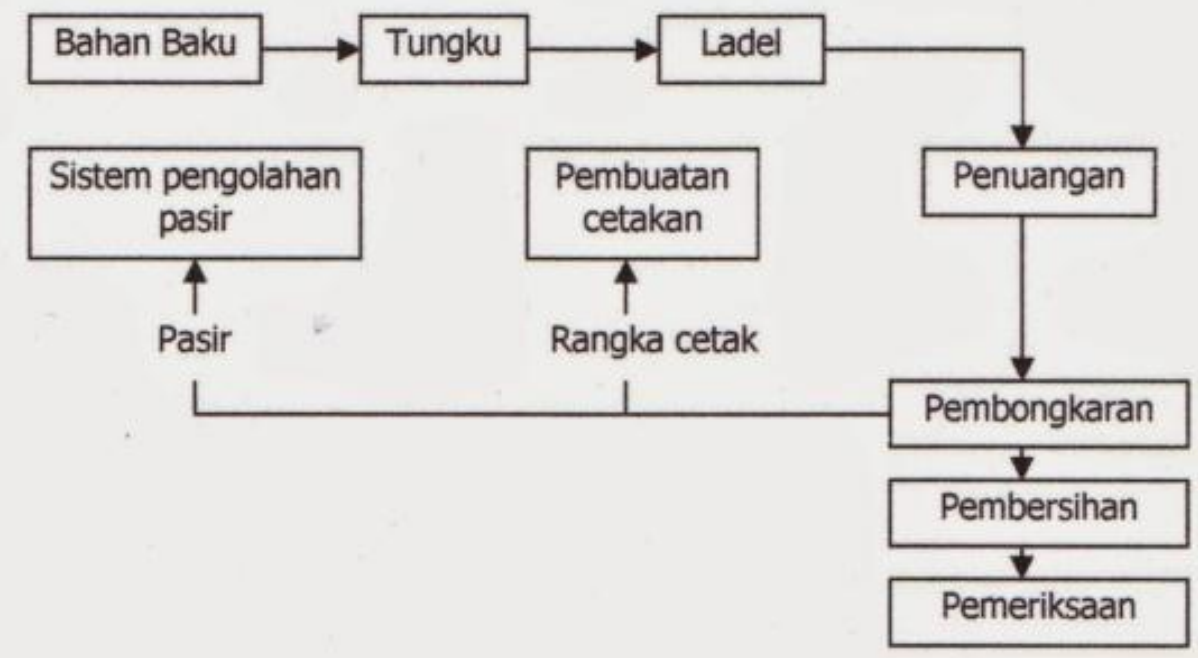

Gambar 1. Diagram Proses Pengecoran Logam

\section{Kuningan}

Kuningan terdiri dari campuran tembaga dan seng. Kuningan juga memiliki ketahanan terhadap korosi. Sifat kuningan yang memiliki kekuatan dan kekerasan yang baik tergantung pada paduan. Kuningan memang pada dasarnya memilki ketahanan yang tinggi terhadap korosi, akan tetapi ada dua permasalahan yang harus diperhatikan. Antara lain pada campuran kuningan yang memiliki kadar seng sangat tinggi, maka paduan yang lainnya akan berkurang seiring dengan bertambahnya kadar seng. Maka dari itu kuningan memiliki keunggulan kuat, tahan aus, dan tahan korosi. Kuningan biasanya memiliki rasio komposisinya yaitu $60 \%$ tembaga dan $40 \%$ seng.

\section{Proses Permesinan}

Proses pemesinan mempunyai beberapa prinsip dasar pemotongan logam yaitu : proses pemotongan dengan mesin press, proses pemotongan konvensional dengan mesin perkakas, dan proses pemotongan non konvensional. Proses pemotongan dengan menggunakan mesin press terdiri dari proses pengguntingan, pengepresan dan penarikan. Proses pemotongan konvensional biasanya menggunakan mesin perkakas adapun terdiri dari proses bubut, proses frais dan sekrap. Proses pemotongan logam ini pada dasarnya dilakukan dengan cara membuang beberapa bagian benda kerja yang tidak diperlukan hingga menjadi beram (chips) sehingga akan terbentuk suatu benda kerja. 
Proses permesinan adalah proses yang dilakukan untuk membuat suatu benda produk jadi dengan menggunakan bahan dasar logam. Biasanya untuk membuat suatu mesin yang komplit menyelesaikannya dengan cara proses permesinan.

Mesin bubut merupakan mesin perkakas yang digunakan untuk menghilangkan sebagian benda kerja yang berbentuk silindris dengan cara membuat sayatan pada benda kerja menggunakan pahat bubut yang digerakkan secara translasi dan sejajar dengan sumbu dari benda kerja yang sedang berputar.

\section{METODE PENELITIAN}

Penelitian ini menggunakan metode eksperimen. Dimana logam kuningan bekas dilebur didalam tungku krusibel kemudian dituang kedalam cetakan pasir selanjutnya didinginkan dengan media air sumur dan pembongkaran cetakan pasir. di lanjutkan dengan proses bubut dan diuji di laboratorium untuk mengetahui nilai kekasaran dan kekerasan bushing, adapun diagram alir penelitian ini dapat dilihat pada Gambar 2.

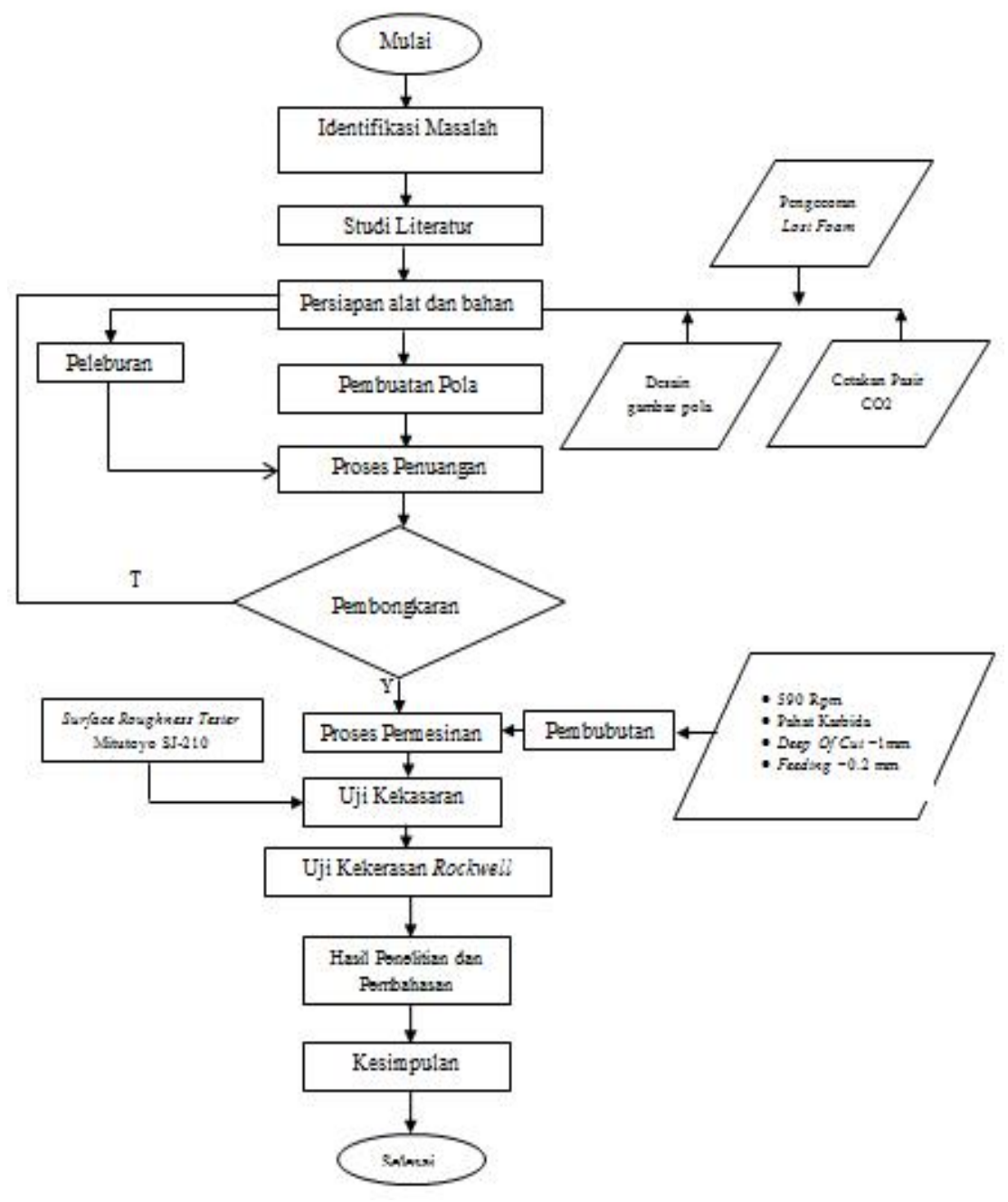

Gambar 2. Diagram Alir Penelitian 


\section{HASIL DAN PEMBAHASAN}

Setelah pola dibuat, kemudian dilakukan proses pengecoran dan permesinan kemudian di uji kekasaran dan kekerasannya menggunakan alat uji rockwell dan surface roughness tester.

\section{Pembuatan Pola}

Pola merupakan bentuk dari benda cor ukuran asli dengan memperhatikan penyusutan dan kelonggaran untuk melakukan permesinan. Ukuran pola untuk bushing roda kereta kapal ditunjukkan pada Gambar 3.
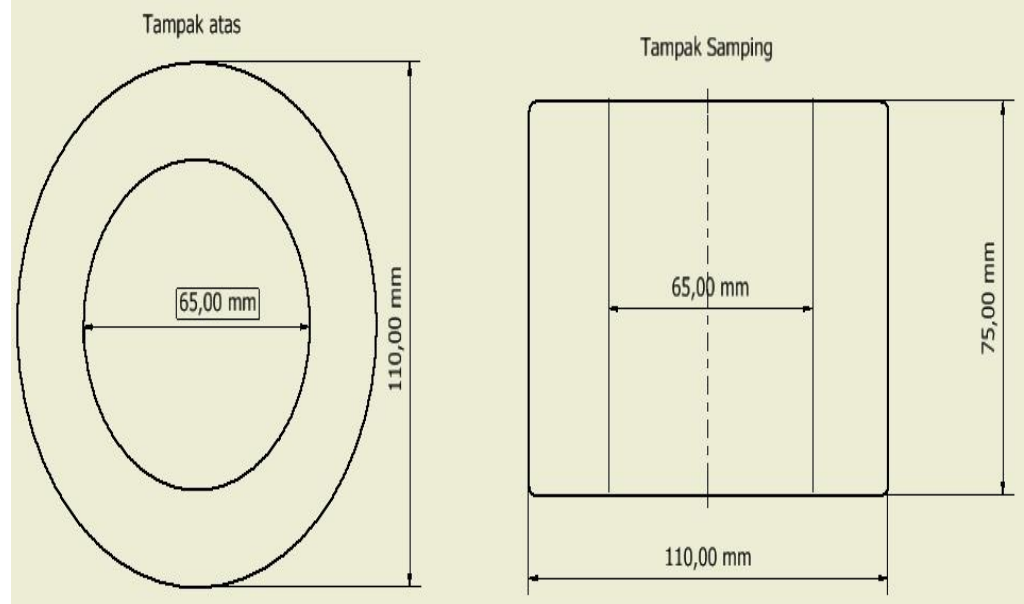

Gambar 3. Ukuran Pola Bushing

\section{Cetakan Pasir $\mathrm{CO}_{2}$}

Jenis pasir $\mathrm{CO}_{2}$ juga disebut cetakan pasir kering dikarenakan memiliki sedikit kadar air yang terdapat dalam cetakan pasir. Cetakan pasir $\mathrm{CO}_{2}$ ini menggunakan pasir silika yang ditambahkan dengan water glass, air, diaduk sampai merata menggunakan mixer kemudian di berikan gas $\mathrm{CO}_{2}$ dan dioleskan dengan grafit agar mempermudah dalam pembongkaran. Cetakan pasir $\mathrm{CO}_{2}$ ditunjukkan pada gambar 4, dimana komposisinya adalah :
a). Pasir silika $\pm 94 \%$.
b). Water glass $\pm 4 \%$.
c). Air $\pm 2 \%$. 


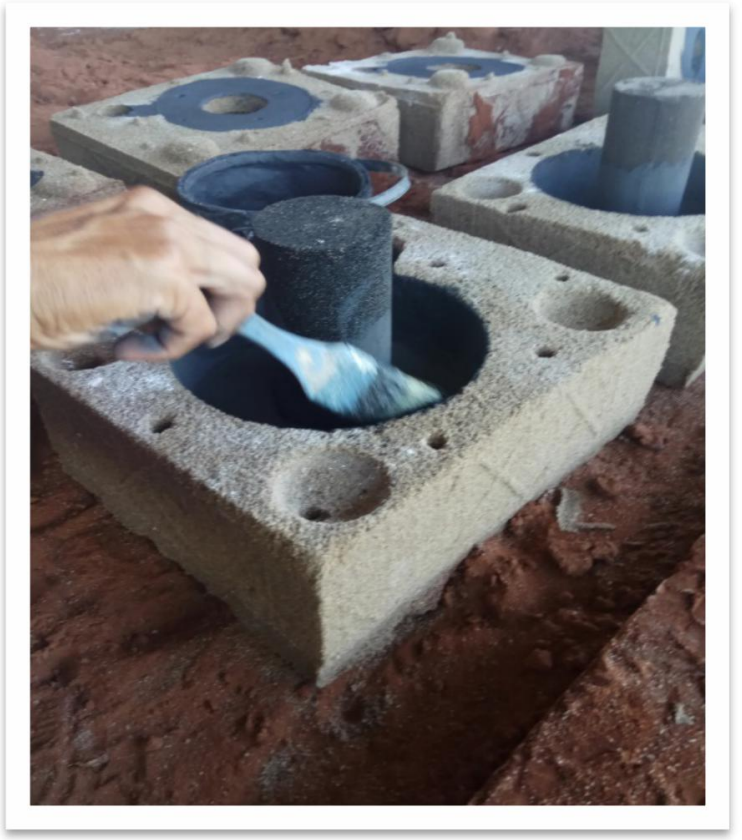

Gambar 4. Cetakan Pasir $\mathrm{CO}_{2}$

\section{Lost Foam Casting}

Lost foam casting merupakan proses pengecoran dimana pasir dipadatkan terlebih dahulu sampai memenuhi pola sekali pakai yang dibuat dari polystyrene kemudian logam cair dituang sampai memenuhi saluran masuk sehingga akan menguapkan pola dan mengisi rongga yang ada pada pola, berikut cetakan pasir evaporatif ditunjukkan pada Gambar 5.

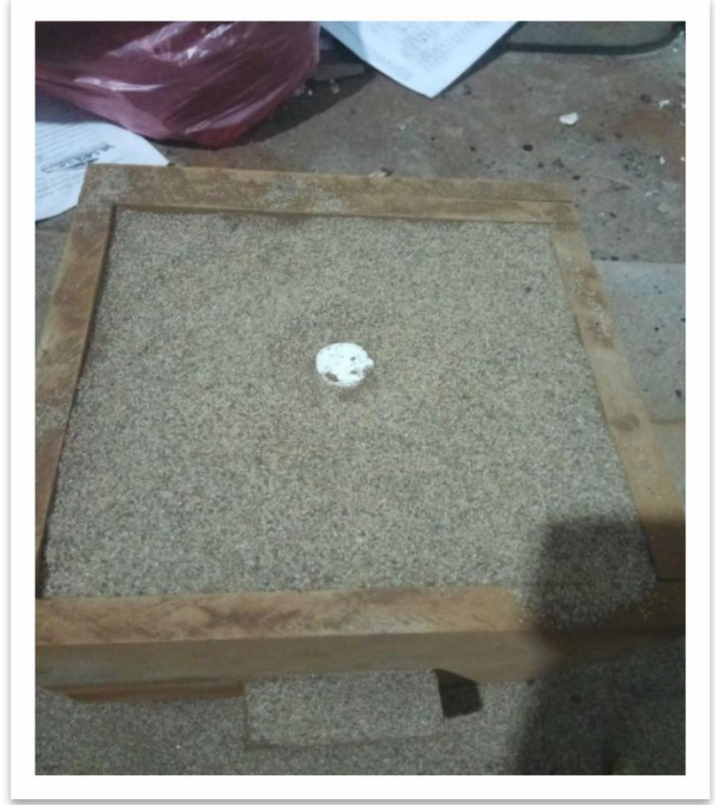

Gambar 5. Cetakan Pasir Evaporatif 


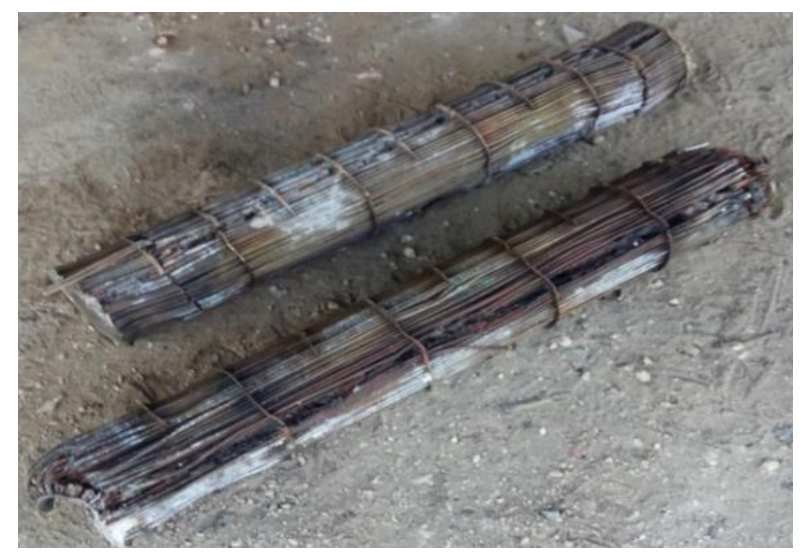

Gambar 6. Tube Bundle Bekas

\section{Proses Peleburan}

Peleburan logam menggunakan bahan kuningan (CuZn) bekas dengan menggunakan energi panas yang dihasilkan oleh tungku sampai dengan suhu 1100 ${ }^{\circ} \mathrm{C}$, kemudian selanjutnya di tuang kedalam cetakan pasir. Berikut merupakan gambar proses peleburan logam kuningan ( $\mathrm{CuZn}$ ) bekas ditunjukkan pada Gambar 7 .

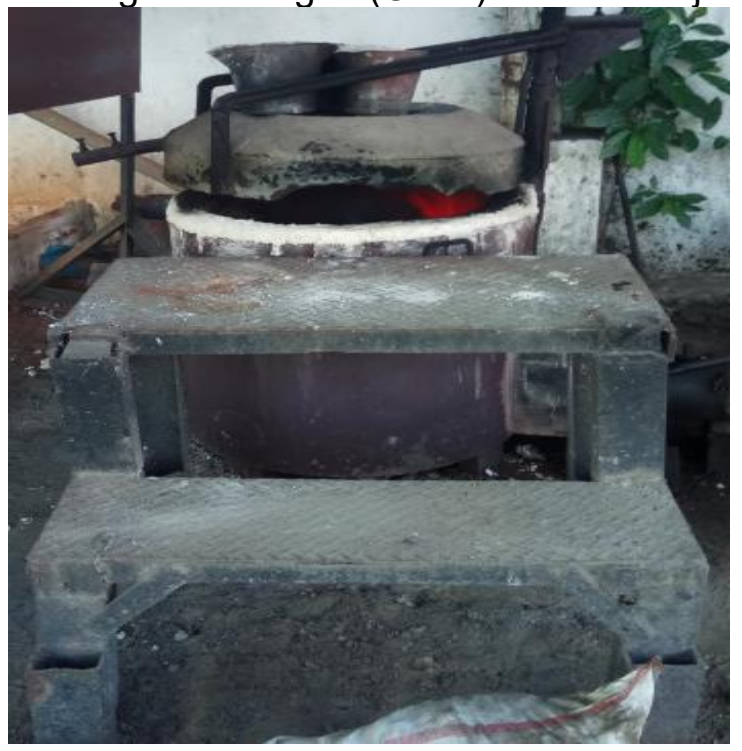

Gambar 7. Proses Peleburan

\section{Penuangan Cairan Logam}

Setelah logam kuningan (CuZn) bekas yang telah dipanaskan hingga menjadi cairan logam kemudian cairan logam di tuang menggunakan cawan tuang kedalam cetakan pasir hingga memenuhi saluran system masuk. Proses penuangan ditunjukkan pada Gambar 8. 


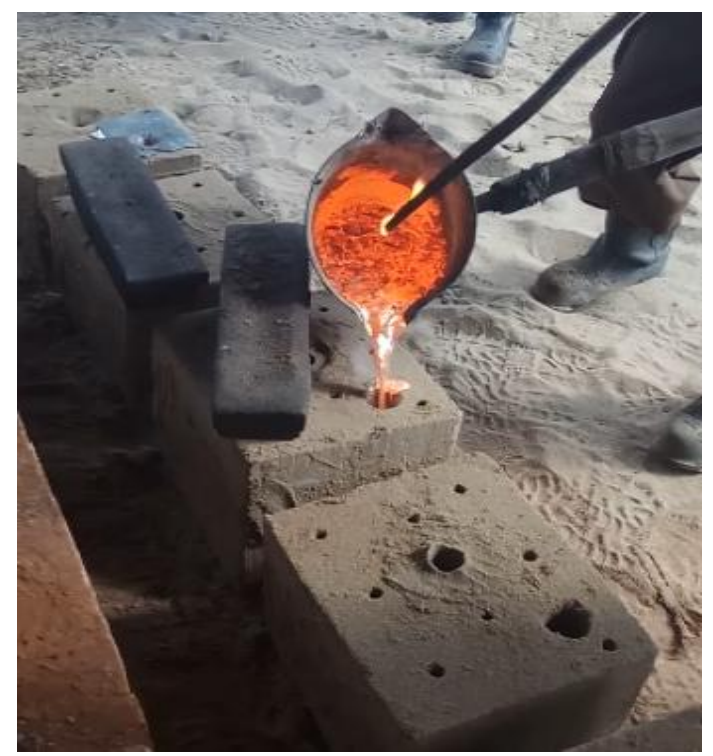

Gambar 8. Proses Penuangan

\section{Pembersihan Coran}

Pembersihan coran terjadi setelah cairan logam di tuang hingga memenuhi sistem saluran masuk dan kemudian di lakukan proses pendingingan menggunakan air sumur, lalu di lakukan pembongkaran cetakan ditunjukkan pada Gambar 9, dan Gambar 10.

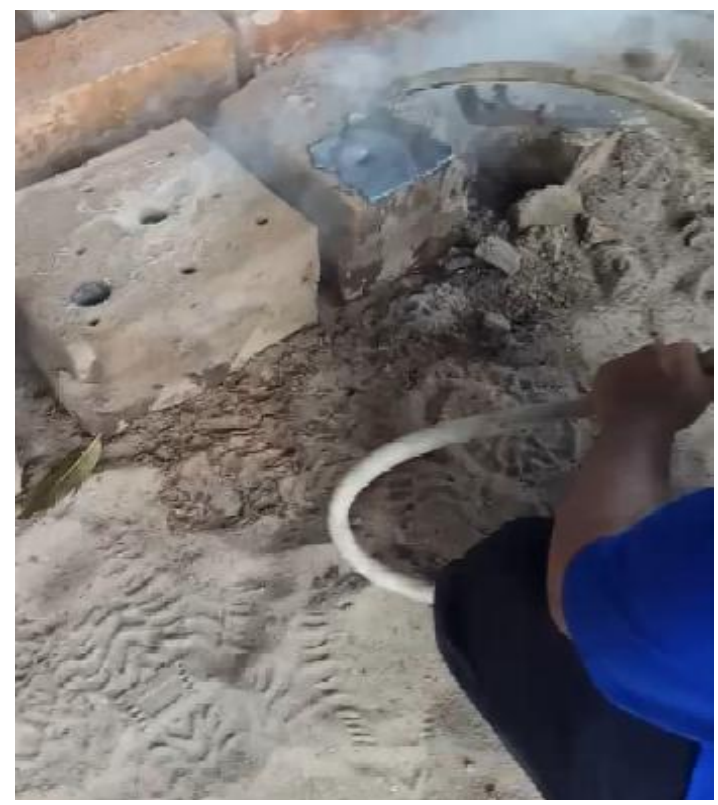

Gambar 9. Proses Pendinginan 


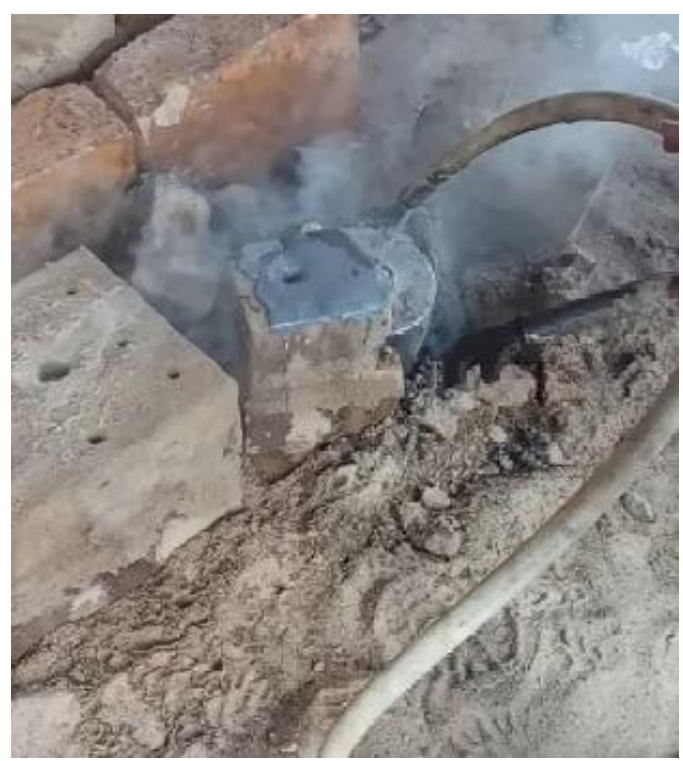

Gambar 10. Proses Pembongkaran

\section{Proses Permesinan Bushing Roda}

Proses permesinan bushing pada penelitian ini menggunakan mesin bubut untuk memotong benda silinder yang di putar pada cekam sehingga memperhalus benda sesuai dengan ukuran yang kita inginkan. Mesin bubut yang digunakan ditunjukkan pada Gambar 11.

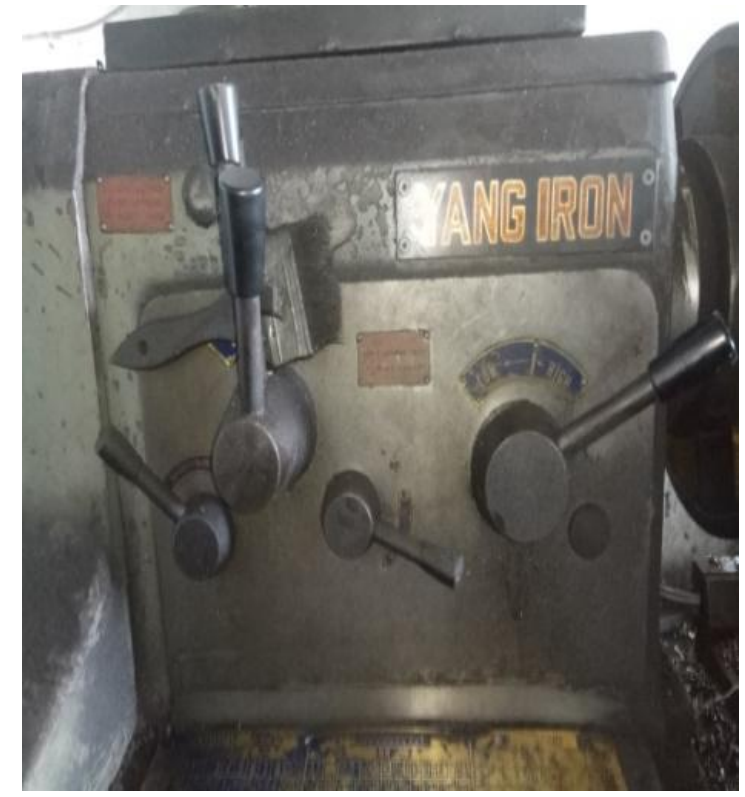

Gambar 11. Mesin Bubut YANG IRON

\section{Pahat}

Pahat yang digunakan ialah pahat carbide karna memiliki ketahanan terhadap abrasi yang tinggi, tahan aus dan resistensi terhadap deformasi termal yang baik. Pahat ini cocok dipakai untuk bahan kuningan. Pahat karbida ditunjukkan pada Gambar 12. 


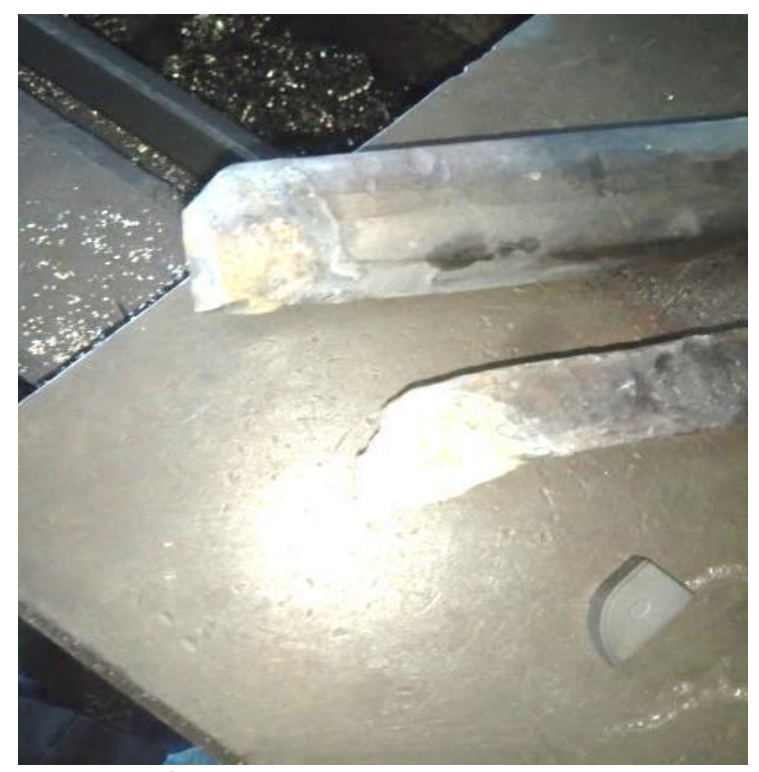

Gambar 12. Pahat Karbida

\section{Proses Pembubutan Facing}

Pembubutan muka atau facing merupakan proses dengan menyayat benda kerja dimana gerakan pahat bubut dalam posisi yang tegak lurus terhadap benda kerja. Metode pembubutan ini digunakan untuk menghilangkan permukaan benda kerja juga untuk mengurangi panjang benda kerja. Ketika melakukan finishing gerakan pahat dari dalam keluar lebih cocok untuk dilakukan. Berikut proses pembubutan facing ditunjukkan pada Gambar 13.

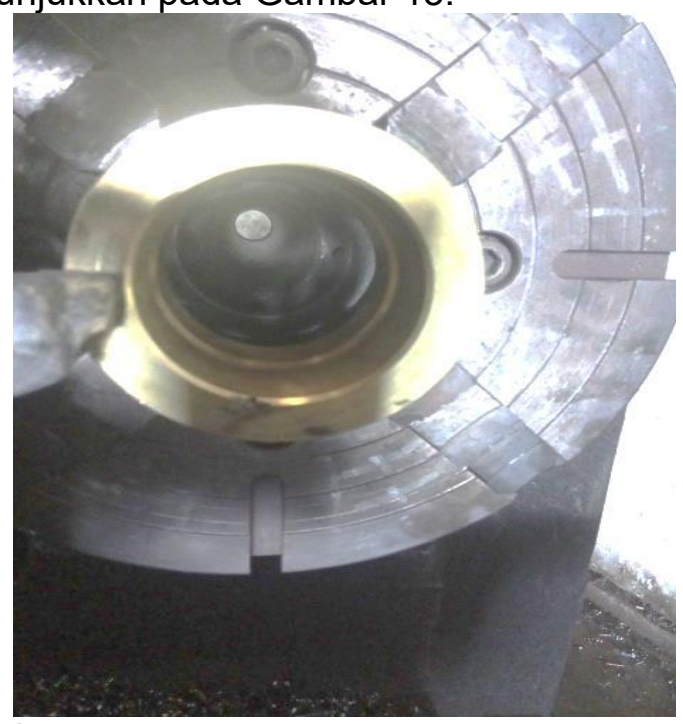

Gambar 13. Proses Pembubutan Facing

\section{Proses Pembubutan Diameter Luar}

Putaran mesin yang digunakan untuk proses pembubutan diameter luar adalah sebesar $590 \mathrm{rpm}$, kecepatan pemakanan yang di peroleh sebesar $118 \mathrm{~mm} / \mathrm{menit}$ dan lama waktu proses pembubutan adalah sebesar 4,77 menit. Proses pembubutan diameter luar ditunjukkan pada Gambar 14. 


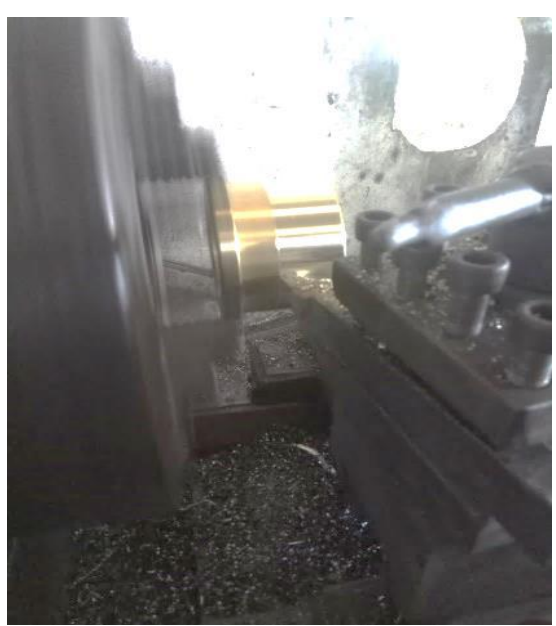

Gambar 14. Proses Pembubutan Diameter Luar

\section{Proses Pembubutan Diameter Dalam}

Proses pembubutan diameter dalam dengan putaran mesin $590 \mathrm{rpm}$, didapatkan kecepatan pemakanan sebesar $118 \mathrm{~mm} / \mathrm{menit}$ dan lama waktu proses bubut sebesar 2,65 menit. Proses pembubutan diameter dalam ditunjukkan pada Gambar 15.

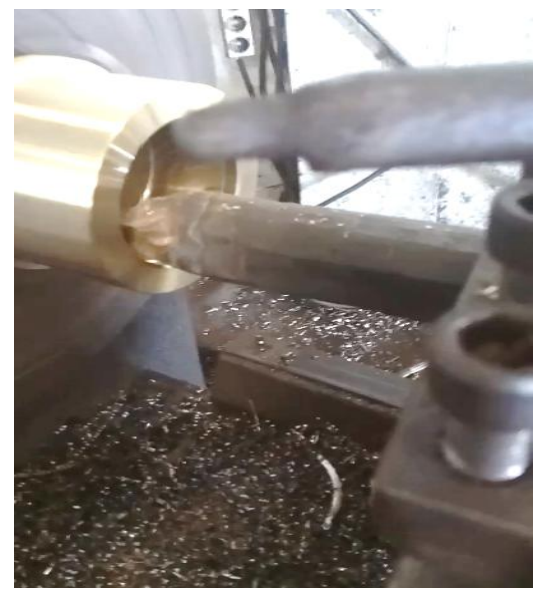

Gambar 15. Proses Pembubutan Diameter Dalam

\section{Pengujian Kekasaran}

Uji kekasaran dilakukan untuk mengukur permukaan pada sebuah benda dan mengetahui nilai tingkat kekasaran maupun tingkat kehalusan pada sebuah bushing roda kereta kapal yang telah di lakukan machining. Kekasaran bushing dapat di ukur dengan menggunakan alat Surface Roughness Tester. Nilai kekasaran dapat disebut dengan Roughness Average (Ra). Dimana Ra merupakan parameter kekasaran yang rata-rata digunakan untuk internasional. Alat ukur yang di gunakan pada penelitian ini adalah Surface Roughness Tester Mitutoyo SJ-210 ditunjukkan pada gambar 17 dan surface roughness standards comparator. ANSI B46.1-1978 ditunjukkan pada Gambar 16. 


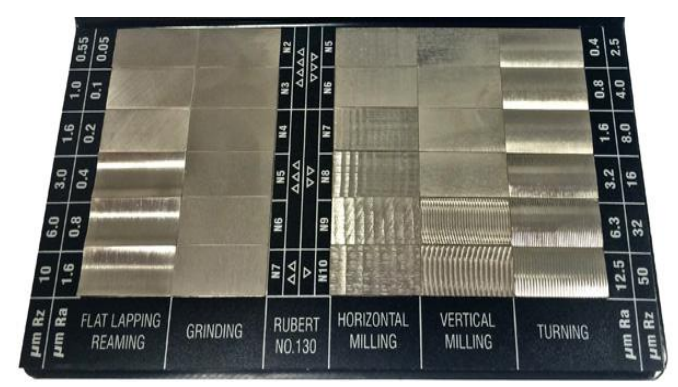

Gambar 16. Surface Roughness Standards Comparator ANSI B46.1-1978

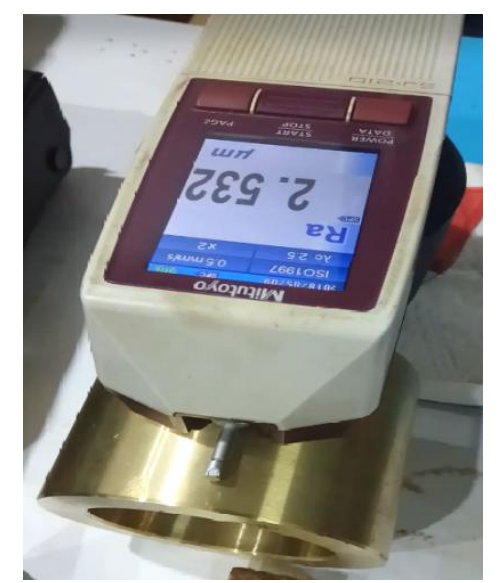

Gambar 17. Pengujian Kekasaran

Data hasil uji kekasaran dengan metode cetakan pasir $\mathrm{CO}_{2}$, evaporatif dan $\mathrm{x}$ yang telah dilakukan pengujian kekasaran dapat dilihat dalam Tabel 1.

Tabel 1. Data Hasil Uji Kekasaran

\begin{tabular}{|c|c|c|c|c|c|c|c|c|}
\hline \multirow{2}{*}{ Metode } & $\begin{array}{c}\text { Posisi } \\
\text { Pengukuran }\end{array}$ & Titik & \multicolumn{2}{|c|}{ A } & \multicolumn{2}{c|}{ B } & \multicolumn{2}{c|}{ C } \\
\hline & & & $\mathrm{Ra}$ & $\mathrm{No}$ & $\mathrm{Ra}$ & $\mathrm{No}$ & $\mathrm{Ra}$ & No \\
\hline \multirow{3}{*}{$\begin{array}{c}\text { Cetakan Pasir } \\
\mathrm{CO}_{2}\end{array}$} & Diameter Luar & $\begin{array}{c}2,532 \\
\mu m\end{array}$ & $\mathrm{~N} 8$ & $\begin{array}{c}2,544 \\
\mu m\end{array}$ & $\begin{array}{c}\mathrm{N} 8 \\
2,673 \\
\mu m\end{array}$ & N8 \\
\cline { 2 - 9 } & Diameter Dalam & $\begin{array}{c}1,539 \\
\mu m\end{array}$ & $\mathrm{~N} 7$ & $\begin{array}{c}1,749 \\
\mu m\end{array}$ & $\mathrm{~N} 8$ & - & - \\
\hline \multirow{2}{*}{\begin{tabular}{c} 
Evaporatif \\
\cline { 2 - 9 }
\end{tabular}} & Diameter luar & - & - & - & - & - & - \\
\cline { 2 - 9 } & Diameter Dalam & - & - & - & - & - & - \\
\hline \multirow{2}{*}{$\mathrm{X}$} & Diameter luar & - & - & - & - & - & - \\
\cline { 2 - 9 } & Diameter Dalam & - & - & - & - & - & - \\
\hline
\end{tabular}

Untuk bushing roda metode evaporatif tidak dapat dilanjutkan uji kekasarannya dikarenakan gagal cetak, dan untuk galangan kapal tidak dapat di lanjutkan karena tidak ada bushing yang masih dalam kondisi baru pada galangan kapal. Gagal cetak bushing dengan metode evaporatif ditunjukkan pada Gambar 18. 


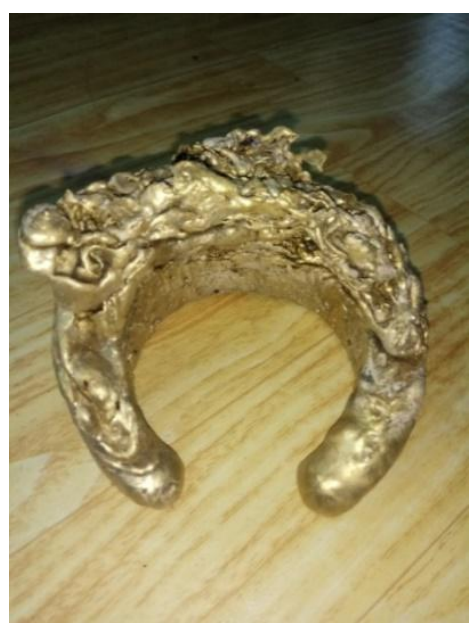

Gambar 18. Gagal Cetak Bushing Metode Evaporatif

\section{Pengujian Kekerasan}

Pengujian kekerasan adalah kemampuan kekuatan suatu bahan terhadap pembebanan dalam perubahan yang tetap. Pengujian kekerasan metode pengujian Hardness Rockwell tipe $\mathrm{B}\left(\mathrm{HR}_{\mathrm{B}}\right)$ dengan pembebanan $100 \mathrm{Kgf}$ serta menggunakan bola baja $1,558 \mathrm{~mm}$ (1/16"), dan dilakukan pembebanan pada 5 titik. Proses pengujian kekerasan ditunjukkan pada Gambar 19.

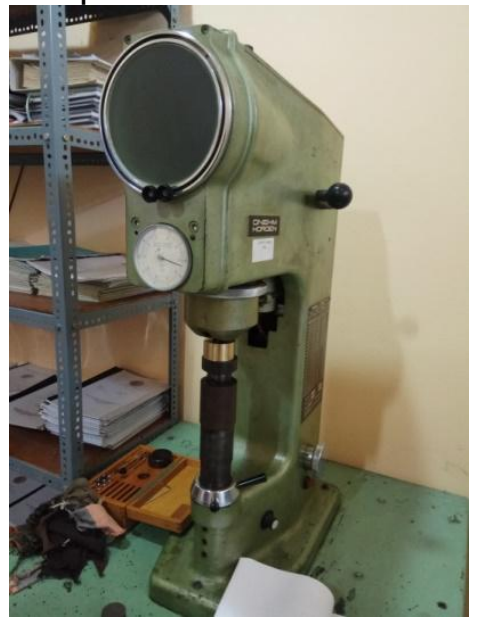

Gambar 19. Proses Pengujian Rockwell

Data hasil pengujian kekerasan menggunakan metode cetakan pasir $\mathrm{CO}_{2}$, evaporatif dan $\mathrm{x}$ dapat dilihat dalam Tabel 2.

Tabel 2. Data Pengujian Kekerasan $\mathrm{HR}_{\mathrm{B}}$

\begin{tabular}{|c|c|c|c|c|c|c|c|}
\hline$N_{0}$ & Metode & Titik1 & Titik2 & Ttik3 & Titik4 & Titik5 & $\begin{array}{c}\text { Rata- } \\
\text { rata HR }\end{array}$ \\
\hline 1 & Cetakan Pasir $\mathrm{CO}_{2}$ & 37 & 43 & 47 & 44 & 39 & 42 \\
\hline 2 & Evaporatif & 33 & 36 & 35 & 32 & 30 & 33,2 \\
\hline 3 & $X$ & 38 & 41 & 43 & 40 & 37 & 39,8 \\
\hline
\end{tabular}


Dari Tabel 2 diatas dapat diperoleh grafik hubungan kekerasan dari metode cetakan pasir $\mathrm{CO}_{2}$, evaporatif dan x ditunjukkan pada Gambar 20.

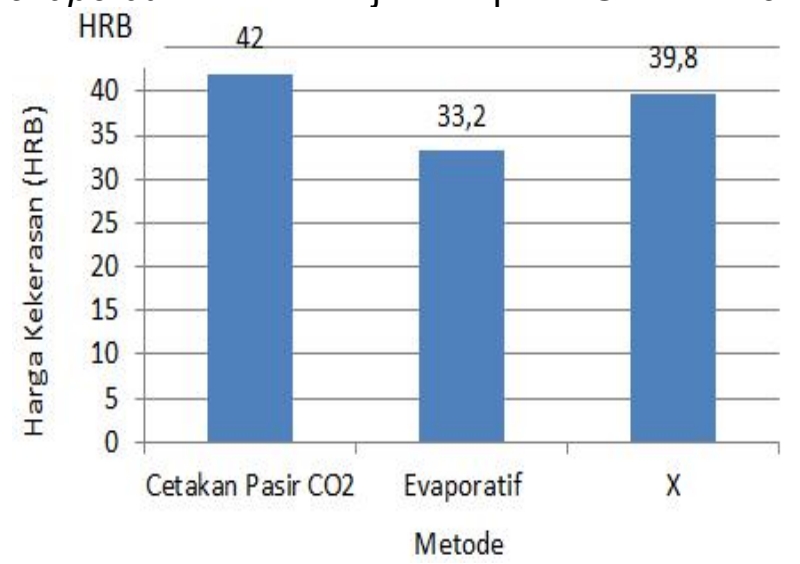

Gambar 20. Grafik hubungan kekerasan

Berdasarkan dari hasil pengujian di atas telah didapatkan nilai kekerasan dengan metode cetakan pasir $\mathrm{CO}_{2}$ sebesar $42 \mathrm{HR}_{\mathrm{B}}$, metode evaporatif sebesar 33,2 $\mathrm{HR}_{\mathrm{B}}$ dan metode dari galangan kapal sebesar $39,8 \mathrm{HR}_{\mathrm{B}}$. Dari semua pengujian yang telah dilakukan nilai kekerasan yang paling besar adalah produk dengan metode cetakan pasir $\mathrm{CO}_{2}$, dikarenakan cetakan pasir $\mathrm{CO}_{2}$ lebih tahan terhadap deformasi panas dan juga memiliki pemadatan pasir yang baik dibandingkan dengan metode evaporatif dan galangan kapal, sehingga cetakan pasir $\mathrm{CO}_{2}$ menghasilkan produk yang lebih baik.

\section{Standar Pengujian Kekerasan}

Menurut ASTM E 140 - 97, bahwa rentang skala rockwell yang dianjurkan adalah 20-100 $\mathrm{HR}_{\mathrm{B}}$ (lihat pada: Tabel 2), untuk metode cetakan pasir $\mathrm{CO}_{2}$ memiliki kekerasan adalah sebesar $41 \mathrm{HR}_{\mathrm{B}}$ (memenuhi syarat), untuk metode evaporatif adalah sebesar $33,2 \mathrm{HR}_{\mathrm{B}}$ (memenuhi syarat) dan metode $\mathrm{x}$ adalah sebesar $39,8 \mathrm{HR}_{\mathrm{B}}$ (memenuhi syarat).

\section{Data Anggaran Biaya}

Data anggaran biaya yang di keluarkan untuk membuat bushing roda kereta kapal dapat dilihat dalam tabel 3.

Tabel 3. Data anggaran biaya

\begin{tabular}{|c|c|c|c|c|c|}
\hline No & Metode & Bahan & Volume & Harga Satuan & Biaya \\
\hline 1 & Cetakan Pasir $\mathrm{CO}_{2}$ & $\begin{array}{l}\text { Upah Pengecoran dan } \\
\text { Pembubutan Bushing }\end{array}$ & 1 Pcs & Rp. $850.000,-$ & Rp. 850.000 ,- \\
\hline & Jumlah & \multicolumn{4}{|c|}{ Rp. $850.000,-$} \\
\hline \multirow{6}{*}{2} & \multirow{6}{*}{ Evaporatif } & Kuningan Bekas & $7 \mathrm{~kg}$ & Rp. 65.000,- & Rp. 455.000,- \\
\hline & & Arang & $10 \mathrm{~kg}$ & Rp. 6.000- & Rp. 60.000,- \\
\hline & & Pasir Silika & $50 \mathrm{~kg}$ & Rp.1.200,- & Rp. 60.000,- \\
\hline & & Upah Pembubutan & 1 PCS & Rp. 70.000- & Rp. 70.000,- \\
\hline & & Styrofoam & $3 \mathrm{PCS}$ & Rp. 12.000 - & Rp. 36.000 \\
\hline & & Lem Gabus & $1 \mathrm{PCS}$ & Rp. 4.000,- & Rp. 4.000,- \\
\hline & Jumlah & & \multicolumn{3}{|c|}{ Rp. 685.000,- } \\
\hline 3 & $x$ & Bushing & $1 \mathrm{Pcs}$ & Rp. 750.000,- & Rp. 750.000,- \\
\hline & Jumlah & \multicolumn{4}{|c|}{ Rp. 750.000} \\
\hline
\end{tabular}


Dapat diketahui dari rencana anggara biaya di atas bahwa untuk metode cetakan pasir $\mathrm{CO}_{2}$ memerlukan biaya sebesar Rp. 850.000,- kemudian metodde evaporatif memerlukan biaya sebesar Rp. 685.000,- dan metode x memerlukan biaya sebesar Rp.750.000,-. Maka biaya yang paling besar terdapat pada cetakan pasir $\mathrm{CO}_{2}$ dan termurah pada evaporatif.

\section{KESIMPULAN}

Berdasarkan hasil penelitian diatas pengecoran yang baik digunakan untuk kuningan adalah dengan metode cetakan pasir $\mathrm{CO}_{2}$ dikarenakan memiliki ketahanan panas yang sangat baik dan kepadatan cetakan pasir yang baik sehingga tidak mengalami gagal cetak. Proses permesinan dengan proses turning menggunakan pahat karbida cocok untuk material berbahan kuningan dikarenakan pahat karbida memiliki ketahanan yang tinggi terhadap abrasi, tangguh resistensi terhadap deformasi termal. Kemudian hasil nilai kekerasan yang terbaik ialah dengan metode cetakan pasir $\mathrm{CO}_{2}$ dengan nilai sebesar $42 \mathrm{HR}_{\mathrm{B}}$.

\section{DAFTAR PUSTAKA}

Adi Simanjuntak, (2011), Pengecoran Logam dan Sejarah Pengecoran Logam. Medan.

Cepi Nugraha, 2013, Proses Permesinan, Surabaya.

Dimas Ambogo, 2017, Pengaruh Variasi Media Cetakan Pasir Kali, Cetakan Pasir $\mathrm{CO}_{2}$ dan Cetakan Logam Terhadap Hasil Produk Flange Coran Alumunium (Al), Surakarta, Universitas Muhammadiyah Surakarta.

Herman Santoso, 2011, Proses Pembuatan Kuningan Dari Logam, Jakarta, Mercu Buana University.

Michael Elkan, 2017, Material Pahat Bubut, Bandung.

Nanda Choirul Amshori, 2014, Proses Pengecoran "Pola Pengecoran".

Rahdiyanta, Dwi, 2010, Materi Kuliah Proses Permesinan (Pengantar), Yogyakarta, Universitas Negeri Yogyakarta.

R. Widodo, 2012, Paduan CuZn (Kuningan), Bandung, Politeknik Manufaktur Bandung.

Taufiq Rochim, 1993, Teori \& Teknologi Proses Permesinan, Bandung.

Yudi Surya Irawan, 2013, Material Teknik, Malang, Universitas Brawijaya. 